\title{
Distribution of Gustatory Sensitivities in Rat Taste Cells: Whole-Cell Responses to Apical Chemical Stimulation
}

\author{
Timothy A. Gilbertson, ${ }^{1}$ John D. Boughter Jr, ${ }^{2}$ Huai Zhang, ${ }^{1}$ and David V. Smith ${ }^{2}$ \\ ${ }_{1}^{1}$ Pennington Biomedical Research Center, Louisiana State University, Baton Rouge, Louisiana 70808-4124, and \\ 2Department of Anatomy and Neurobiology and Program in Neuroscience, University of Maryland School of Medicine, \\ Baltimore, Maryland 21201-1509
}

Several taste transduction mechanisms have been demonstrated in mammals, but little is known about their distribution within and across receptor cells. We recorded whole-cell responses of 120 taste cells of the rat fungiform papillae and soft palate maintained within the intact epithelium in a modified Ussing chamber, which allowed us to flow tastants across the apical membrane while monitoring the activity of the cell with a patch pipette. Taste stimuli were: $0.1 \mathrm{M}$ sucrose, $\mathrm{KCl}$, and $\mathrm{NH}_{4} \mathrm{Cl}, 0.032 \mathrm{M} \mathrm{NaCl}$, and $3.2 \mathrm{~mm} \mathrm{HCl}$ and quinine hydrochloride $(\mathrm{QHCl})$. When cells were held at their resting potentials, taste stimulation resulted in conductance changes; reversible currents $>5 \mathrm{pA}$ were considered reliable responses. Sucrose and $\mathrm{QHCl}$ produced a decrease in outward current and membrane conductance, whereas $\mathrm{NaCl}, \mathrm{KCl}, \mathrm{NH}_{4} \mathrm{Cl}$, and $\mathrm{HCl}$ elicited inward currents accompanied by increased conductance.

Taste transduction involves a variety of mechanisms, including direct permeation or block of ion channels and activation of metabotropic and ionotropic receptors (for review, see Lindemann, 1996; Herness and Gilbertson, 1999). There is little information, however, about how these mechanisms are distributed within and across taste receptor cells. Intracellular recording experiments have suggested that taste cells are broadly responsive to stimuli representing different taste qualities (Kimura and Beidler, 1961; Ozeki and Sato, 1972; Tonosaki and Funakoshi, 1984; Sato and Beidler, 1997). However, because of their relatively small membrane potentials and the possibility of leak currents associated with penetrating such small cells with sharp electrodes, many investigators have viewed these intracellular experiments with skepticism (Kinnamon, 1988; Avenet and Lindemann, 1989; Lindemann, 1996; Herness and Gilbertson, 1999). More recent experiments have used patch-clamp recording methods on isolated taste receptor cells (Avenet and Lindemann, 1987; Akabas et al., 1988; Kinnamon et al., 1988; Gilbertson et al., 1993; Herness and Sun, 1995; Chen et al., 1996; Cummings et al., 1996), but the range of stimuli that can be applied to an isolated cell

\footnotetext{
Received Jan. 25, 2001; revised April 2, 2001; accepted April 19, 2001.

This work was supported in part by National Institute on Deafness and Other Communication Disorders Grants DC00353 (D.V.S.) and DC02507 (T.A.G.). We thank W. Todd Monroe for help in the early phases of design and testing of the chamber used in this study and the expert technical assistance of Nikki D. Siears, Alicia Lumpkin, and Holly Lively.

Correspondence should be addressed to Dr. David V. Smith, Department of Anatomy and Neurobiology, University of Maryland School of Medicine, 685 West Baltimore Street, Baltimore, MD 21201-1509. E-mail: dvsmith@umaryland.edu.

T. A. Gilbertson's present address: Department of Biology, Utah State University, Logan, UT 84322-5305.

Copyright (C) 2001 Society for Neuroscience $\quad 0270-6474 / 01 / 214931-11 \$ 15.00 / 0$
}

Combinations of responses to pairs of the four basic stimuli (sucrose, $\mathrm{NaCl}, \mathrm{HCl}$, and $\mathrm{QHCl}$ ) across the 71-84 cells tested with each pair were predictable from the probabilities of responses to individual stimuli, indicating an independent distribution of sensitivities. Of 62 cells tested with all four basic stimuli, 59 responded to at least one of the stimuli; 16 of these (27.1\%) responded to only one, 20 (33.9\%) to two, $15(25.4 \%)$ to three, and $8(13.6 \%)$ to all of the basic stimuli. Cells with both inward $\left(\mathrm{Na}^{+}\right)$and outward $\left(\mathrm{K}^{+}\right)$voltage-activated currents were significantly more broadly tuned to gustatory stimuli than those with only inward currents.

Key words: taste receptor cell; tongue epithelium; palate epithelium; gustatory sensitivity; breadth of tuning; sucrose; quinine; salt; acid; pattern coding preparation is limited and recording is hindered by having the apical and basolateral membranes in the same bathing medium.

In contrast, there is a great deal of information on the sensitivities of gustatory afferent fibers and central neurons. There is general consensus that afferent neurons, from the gustatory nerves to forebrain taste areas, show multiple sensitivity to stimuli representing different taste qualities (Pfaffmann, 1955, 1959; Ogawa et al., 1968; Smith et al., 1983; Yamamoto et al., 1984; Frank et al., 1988; Ninomiya and Funakoshi, 1988; Smith and Frank, 1993). Moreover, as information is passed from the gustatory afferent nerves to brainstem nuclei, the cells become more broadly tuned because of convergence at each successive stage (Smith and Travers, 1979; Travers and Smith, 1979; Van Buskirk and Smith, 1981; Sweazey and Smith, 1987; Frank et al., 1988). Thus, most levels of the gustatory system are characterized by broadly tuned afferent neurons.

To determine whether the taste receptor cells themselves contribute to this broad tuning and to examine the distribution of gustatory sensitivities across these cells, we have combined patchclamp recording with apically restricted stimulus application. Whole-cell recordings were made from 120 receptor cells maintained in the intact epithelium of the soft palate or the anterior portion of the tongue. Up to six taste stimuli were applied to the apical membrane of each cell by perfusion through a closed mucosal chamber, which effectively separated the apical from the basolateral taste cell membranes. The data show that individual taste receptor cells often exhibit a range of chemical sensitivities. Almost three-quarters of the cells responded to more than one of four basic taste stimuli, although the receptor cells showed greater stimulus specificity than typically seen in first- or second- 
order afferent neurons. Thus, one source of the multiple sensitivity of peripheral and central gustatory neurons arises at the initial step of stimulus recognition by the taste receptor cells themselves.

Portions of these results have appeared in abstract form (Monroe et al., 1996; Gilbertson et al., 1999; Smith et al., 2000).

\section{MATERIALS AND METHODS}

Tissue preparation. Epithelial tissue was prepared from the anterior tongues or soft palates of 2- to 6-month old Sprague Dawley rats using established methods (Béhé et al., 1990b; Gilbertson, 1995) that have been adapted for intact epithelial preparations (Gilbertson and Zhang, 1998). Briefly, tongues or palates were injected between the epithelium and underlying tissue with $\sim 1.0 \mathrm{ml}$ of Tyrode containing $0.5 \mathrm{mg} / \mathrm{ml}$ collagenase A, $2.5 \mathrm{mg} / \mathrm{ml}$ dispase (type II; Boehringer Mannheim, Indianapolis, IN), and $1 \mathrm{mg} / \mathrm{ml}$ trypsin inhibitor (type I-S; Sigma, St. Louis, MO). Once injected, tissues were incubated for $\sim 20 \mathrm{~min}$ at room temperature in $\mathrm{Ca}^{2+} / \mathrm{Mg}^{2+}$-free Tyrode and bubbled with $\mathrm{O}_{2}$. The lingual or palatal epithelia were peeled from the underlying tissue after incubation, rinsed several times with enzyme-free Tyrode, and pinned out in a Sylgardlined Petri dish with the mucosal side down. Plastic coverslips $(15 \mathrm{~mm}$, Thermanox plastic; Nunc, Naperville, IL) with a $2-3 \mathrm{~mm}$ hole through the center were coated with a thin layer of cyanoacrylate glue and placed on both sides of the isolated epithelium. Generally, from two to six or more taste buds were accessible in the opening of the coverslip, as shown in Figure $1 A$, which depicts the serosal side of the tongue epithelium. Under differential interference contrast (DIC) illumination, individual cells within the taste buds could be discerned (Fig. 1B). In this configuration, it was possible (see below) to deliver gustatory stimuli to the apical membranes of the cells via the taste pore, shown from the mucosal side of the epithelium in Figure $1 C$. The time course of solution change at the mucosal surface is shown in Figure $1 D$, which depicts the current change caused by the liquid junction potential of a patch pipette (filled with $30 \mathrm{~mm} \mathrm{KCl}$ ) placed on the mucosal side of the chamber. When the mucosal solution was switched from 30 to $300 \mathrm{mM} \mathrm{KCl,} 10 \mathrm{sec}$ were required to effect a complete change of stimulus solution.

Modified Ussing chamber. The epithelial preparation was mounted in a bipartitioned chamber separating the mucosal and serosal surfaces of the epithelium (Fig. 2). Both sides of the epithelium were initially perfused with Tyrode. This configuration is a variation of the classic Ussing chamber; it allows taste stimuli to be presented to the apical membranes of the taste cells via the closed mucosal chamber, while permitting access to the basolateral membranes with a patch electrode (Fig. 2B). Similar approaches have been attempted in the past with some success for intracellular, patch, and optical recording (Roper and McBride, 1989; Béhé et al., 1990a; Furue and Yoshii, 1997, 1998; Ohtubo et al., 2001). In the course of the present study, we have used several different designs for this modified Ussing (MU) chamber that all retain the same basic features (Fig. 2). For the taste solutions, as many as eight reservoirs could be connected to an 8-to-1 valve, the output of which was directed into a $5 \mathrm{ml}$ flow reservoir, which in turn was connected to the input line of the mucosal chamber with PE-190 tubing (Becton Dickinson, Sparks, MD). The volume of the mucosal chamber was $65 \mu \mathrm{l}$, and the flow rate was 2.3 $\mathrm{ml} / \mathrm{min}$. The flow reservoir served to prevent epithelial movement during solution changes by keeping a constant head of pressure on the mucosal chamber (Furue and Yoshii, 1998). Stimulus solutions flowing into the reservoir replaced the distilled water in $\sim 10 \mathrm{sec}$, as reflected in the current changes shown in Figure $1 D$. Solution output was collected passively and removed by suction. The serosal solution was provided by gravity flow from a $500 \mathrm{ml}$ reservoir containing Tyrode. The ground electrode $(150 \mathrm{~mm} \mathrm{NaCl}$ in $4 \%$ agarose) was placed in the serosal chamber. Epithelia placed in the chamber and perfused with Tyrode in the serosal chamber were stable for a minimum of 3-4 hr without noticeable electrophysiological decrement.

The chemosensitivity of the cells was examined by flowing from one to six of the following taste stimuli through the mucosal chamber (in mM): sucrose, 100; quinine- $\mathrm{HCl}(\mathrm{QHCl}), 3.2 ; \mathrm{KCl}, 100 ; \mathrm{NaCl}, 32$; citric acid, 3.2; $\mathrm{HCl}, 3.2$; and $\mathrm{NH}_{4} \mathrm{Cl}, 100$. The mucosal epithelium was adapted to distilled $\mathrm{H}_{2} \mathrm{O}$, as is typically done in electrophysiological experiments on peripheral gustatory nerve fibers or central neurons in vivo. These solutions and their concentrations are similar to those used in earlier recordings of taste responses in chorda tympani fibers, the greater superficial petrosal nerve, and the nucleus of the solitary tract of the rat
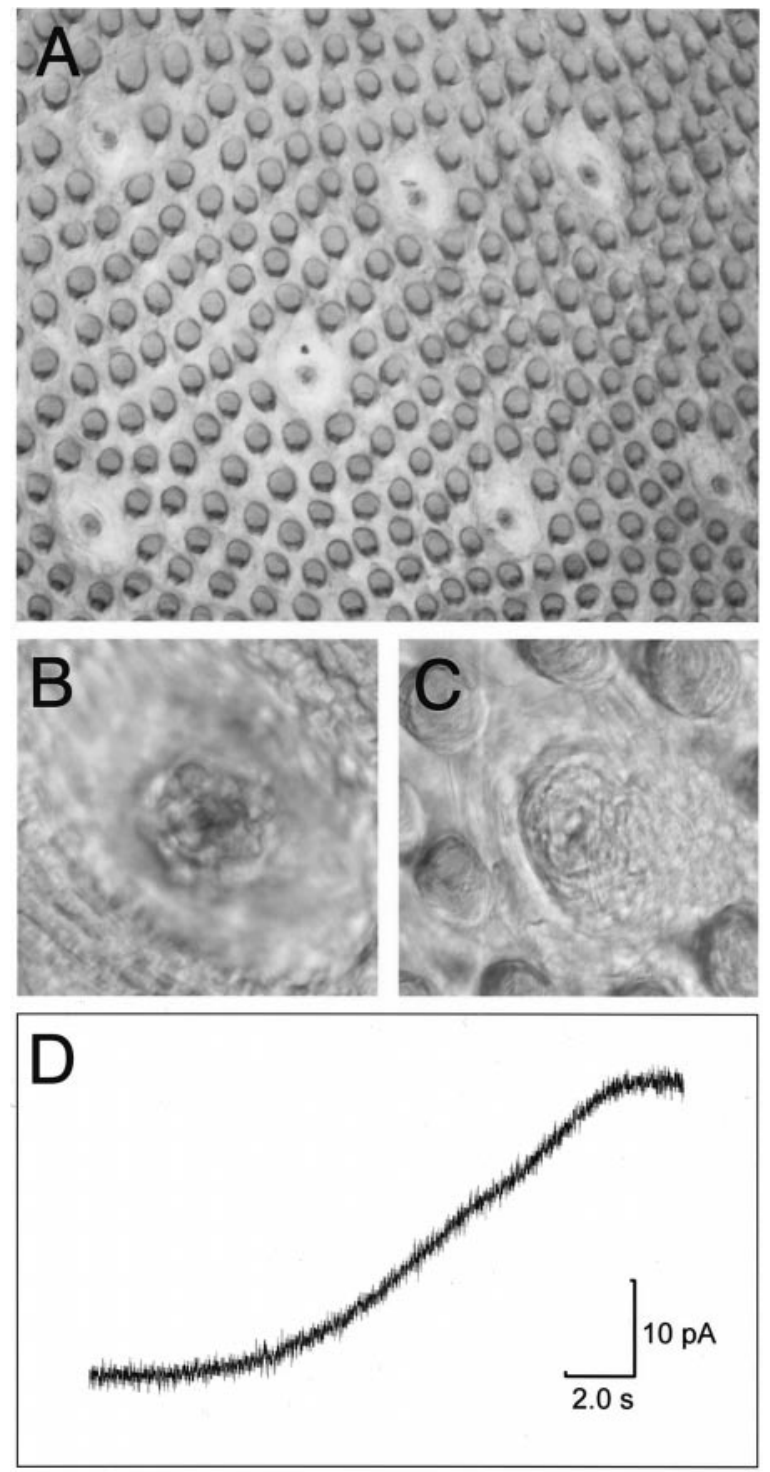

Figure 1. Photomicrographs of the lingual epithelium, after enzymatic removal from the anterior portion of the tongue. $A$, At low power, viewed from the serosal (basolateral) side of the epithelium, several taste buds within fungiform papillae can be seen amid the numerous filiform papillae in a freshly isolated strip of epithelium. $B$, At higher power and under DIC illumination, individual cells in the taste bud can be visualized. $C$, Taste pore of an individual taste bud, viewed from the mucosal side of the epithelium. Tastants applied to the mucosal surface have access to the taste bud only through the taste pore. $D$, Change in current produced by the liquid junction potential of a micropipette filled with $30 \mathrm{~mm} \mathrm{KCl}$ when the mucosal solution was switched from 30 to $300 \mathrm{~mm} \mathrm{KCl}$.

(Pfaffmann, 1955; Frank and Pfaffmann, 1969; Doetsch and Erickson, 1970; Contreras and Frank, 1979; Frank et al., 1983).

Solutions and recording conditions. Extracellular saline (Tyrode) contained (in mM): $\mathrm{NaCl}, 140 ; \mathrm{KCl}, 5, \mathrm{CaCl}_{2}, 1 ; \mathrm{MgCl}_{2}, 1$; HEPES, 10 ; glucose, 10 ; and $\mathrm{Na}^{+}$pyruvate, 10 . The $\mathrm{pH}$ was adjusted to 7.40 with $\mathrm{NaOH}$. The only change made to prepare $\mathrm{Ca}^{2+} / \mathrm{Mg}^{2+}$-free Tyrode was to substitute $2 \mathrm{~mm}$ BAPTA (Molecular Probes, Eugene, OR) for the $\mathrm{CaCl}_{2}$ and $\mathrm{MgCl}_{2}$. The pipette solution contained (in $\mathrm{mM}$ ): $\mathrm{KCl}, 140$; $\mathrm{CaCl}_{2}, 1 ; \mathrm{MgCl}_{2}, 2$; HEPES, 10; EGTA, 11; $\mathrm{Na}_{2} \mathrm{ATP}, 5$; GTP, 0.4. The $\mathrm{pH}$ was adjusted to 7.20 with $\mathrm{KOH}$ and the free $\mathrm{Ca}^{2+}$ was $\sim 10^{-8} \mathrm{M}$

Recordings were made from individual taste receptor cells maintained in intact taste buds using the conventional whole-cell variation of the patch-clamp technique (Hamill et al., 1981). Patch pipettes were made from microhematocrit tubes (Scientific Products, McGaw Park, IL) pulled on a Flaming-Brown-type micropipette puller (model P-97; Sutter 


\section{A} mucosal reservoirs

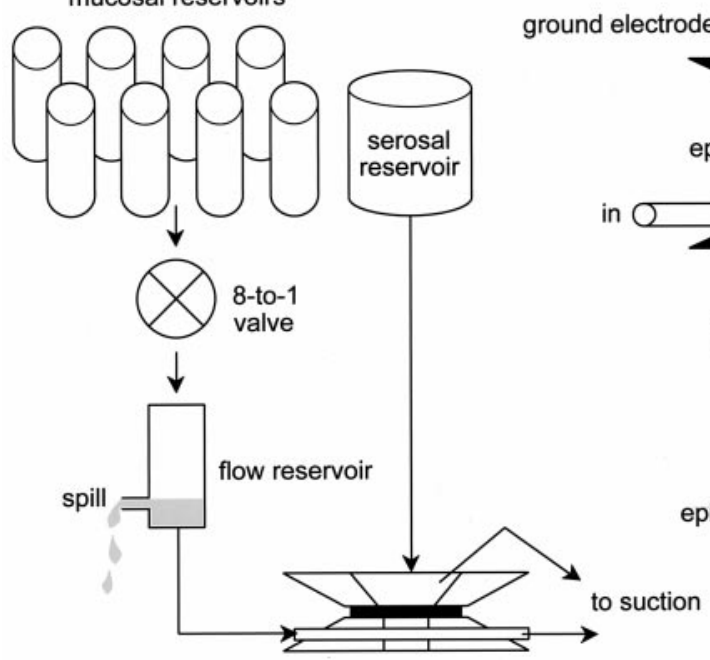

B patch pipette

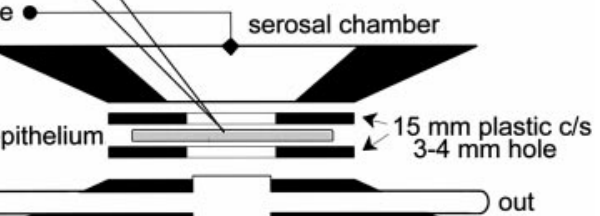

mucosal chamber

C patch pipette epithelium

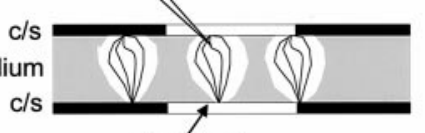

taste bud

Figure 2. Schematic diagrams of the MU chamber. A, The MU chamber consisted of two separate chambers, each with its own perfusion system. The mucosal (apical) chamber was fed by eight solution reservoirs connected via an eight-way solenoid valve to a flow reservoir and, in turn, to the chamber. The serosal (basolateral) chamber was perfused with Tyrode. $B, C$, Detailed views of the MU chamber. The lingual epithelium containing taste buds of the fungiform papillae was mounted with cyanoacrylate glue between two plastic coverslips $(c / s)$ each of which had a $\sim 3$ mm hole drilled through it. This hole permitted access to several taste buds per preparation. Orientation of the epithelium was such that the apical (chemoreceptive) ends of the taste cells faced into the stimulating mucosal solution, which accessed the apical membranes through the taste pore. The patch pipette had access to the basolateral regions of the cells via the serosal chamber.

Instruments, Novato, CA) and fire-polished on a microforge (model MF-9; Narishige, Tokyo, Japan) to a resistance of 4-8 M $\Omega$ when filled with intracellular solution. Seal resistances were typically in the tens of G $\Omega$ s. Series resistance and capacitance were compensated before recording.

Whole-cell membrane currents or voltages were recorded in voltageclamp or current-clamp modes, respectively, by a high-impedance patchclamp amplifier (Axopatch 1-D; Axon Instruments, Foster City, CA) interfaced to a computer (Pentium $90 \mathrm{MHz}$ ) by an analog-to-digital board (Digidata 1200A; Axon Instruments). Command potentials were delivered and currents recorded by computer-driven software (pClamp 6.0.3/7.0; Axon Instruments). In some experiments, steady-state current responses were recorded on VCR $(44.1 \mathrm{kHz})$ and printed on a strip chart recorder (model RS3200; Gould Instrument Systems, Valley View, OH). Steady-state currents and voltage-activated currents were recorded at a sampling rate of $10 \mathrm{kHz}$. For analysis and presentation, data were low-pass filtered at $2 \mathrm{kHz}$. Once the whole-cell configuration was established, compensation for series resistance and cell capacitance was made. No records were leak-subtracted. Once in the whole-cell configuration, we tested every cell under voltage clamp for the evidence of voltageactivated $\mathrm{Na}^{+}$and/or $\mathrm{K}^{+}$current (Fig. 3) as an indicator that we were recording from receptor cells and not epithelial cells, which lack these currents (Akabas et al., 1990). In the initial experiments, we recorded the tastant-induced change in membrane potential in current-clamp mode with the cell held at or near its resting potential (Fig. 4). In these experiments, tetrodotoxin $(0.5 \mathrm{mM})$ was included in the serosal chamber to inhibit action potential generation. However, we subsequently found that we had better success using voltage-clamp mode. In this configuration, the cell was held near its resting potential and we recorded the effects of tastants on the resting conductance (Fig. 5). Data were consistent using both modes of recording.

Data analysis. Stimulus-induced changes in voltage or current were recorded while the cells were held near their resting potentials. In the initial current-clamp experiments, a reversible change in membrane potential $\geq 5 \mathrm{mV}$ that was time-locked to the stimulus application was considered a clearly discernable response. Most of the data were obtained in voltage-clamp mode, where a temporally associated reversible current $\geq 5 \mathrm{pA}$ was the response criterion; for some analyses a more stringent $10 \mathrm{pA}$ criterion was used. All stimulus-induced current changes $\geq 5 \mathrm{pA}$ were recorded, and the actual current values for the 62 cells that were tested with all four of the basic stimuli (sucrose, $\mathrm{NaCl}, \mathrm{HCl}$ and $\mathrm{QHCl}$ ) are provided in Tables 1 and 2. Although ramping through a
A: Control

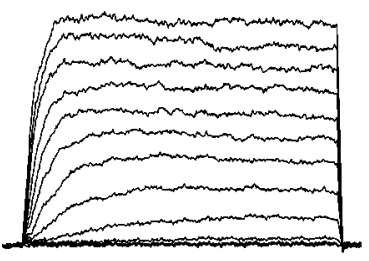

C: Control

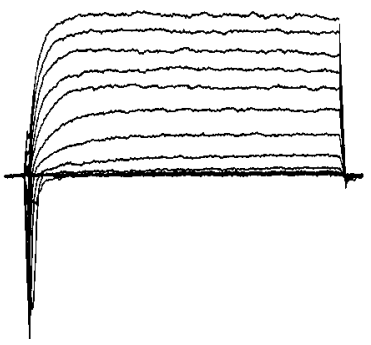

B: $10 \mathrm{mM} 4-\mathrm{AP}$ +10 mM TEA

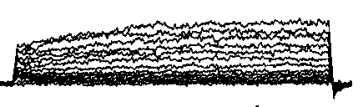

$100 \mathrm{pA}$
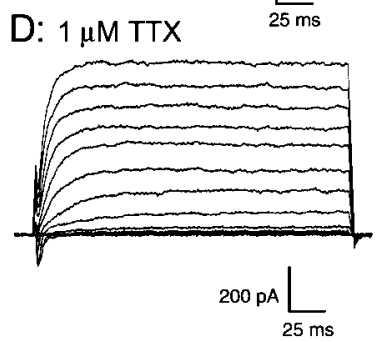

Figure 3. Voltage-activated currents recorded from two taste cells in the MU chamber. Cells were held at $-80 \mathrm{mV}$ and stepped to $+40 \mathrm{mV}$ in 10 $\mathrm{mV}$ increments. The cell in $A$ showed only voltage-activated outward currents, which were reduced by the addition of $10 \mathrm{~mm} 4-\mathrm{AP}$ and $10 \mathrm{~mm}$ TEA to the serosal bath $(B)$. The cell in $C$ showed both inward and outward currents; the inward currents were reduced by the addition of 1 $\mu \mathrm{M}$ TTX to the serosal bath $(D)$.

series of voltages would have provided us with greater detail on the current-voltage relationships of these cells, we wished to determine whether taste stimuli would alter the conductance of these cells when they were at resting membrane potential.

The breadth of responsiveness of the cells was determined by using a criterion-free measure of breadth of tuning, which compares the relative magnitudes of responses within each cell. Breadth of tuning was quantified using the entropy equation first introduced for measuring breadth 

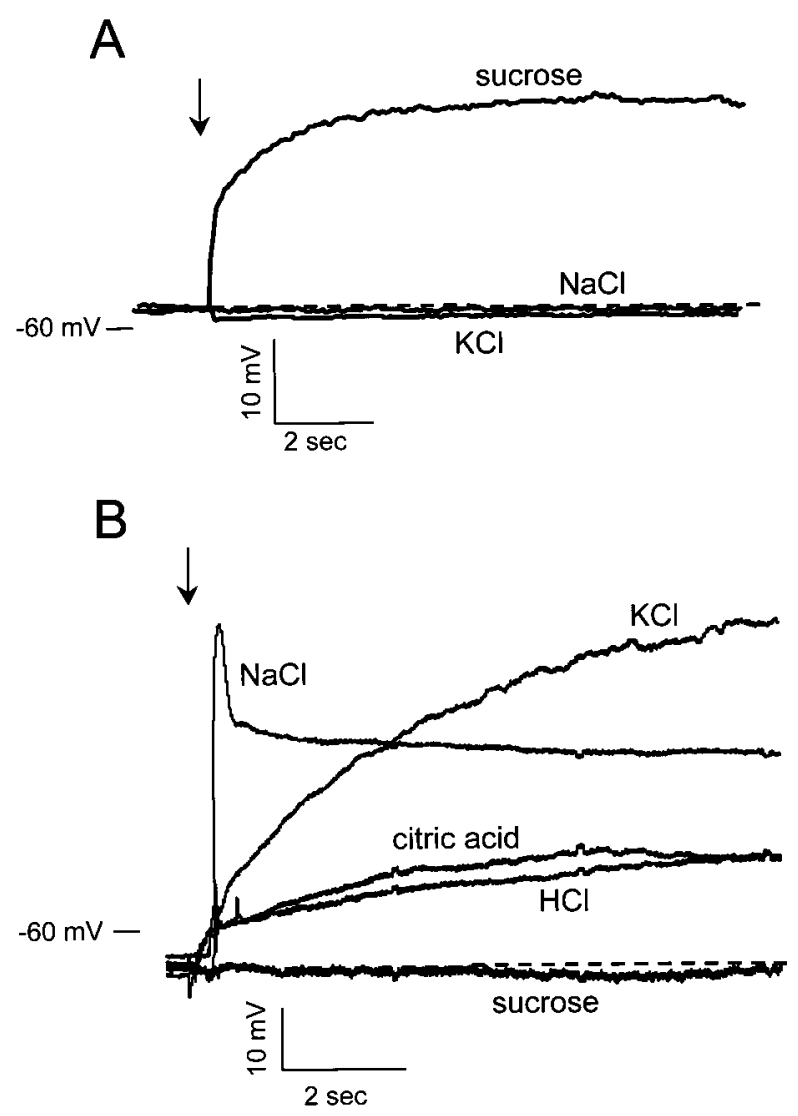

Figure 4. Current-clamp responses of taste receptor cells to various gustatory stimuli. The two cells were held near their respective resting potentials ( $-58 \mathrm{mV}$ in $A ;-63 \mathrm{mV}$ in $B$ ), and taste stimuli were perfused onto the mucosal surface of the epithelium. $A$, This cell was depolarized by $0.1 \mathrm{M}$ sucrose, but not by $0.032 \mathrm{M} \mathrm{NaCl}$ or $0.1 \mathrm{M} \mathrm{KCl}$. B, Voltage response of a broadly sensitive cell that was reversibly depolarized by $0.032 \mathrm{M} \mathrm{NaCl}, 0.1 \mathrm{M} \mathrm{KCl}, 3.2 \mathrm{~mm}$ citric acid, and $3.2 \mathrm{~mm} \mathrm{HCl}$, but not by $0.1 \mathrm{M}$ sucrose. Stimulation began at the arrow and continued throughout the time period shown; $0.5 \mathrm{~mm}$ TTX was present in the serosal solution.

of gustatory sensitivity by Smith and Travers (1979). Entropy $(H)$ is given by:

$$
H=-K \sum_{i=1}^{n} p_{\mathrm{i}} \log p_{\mathrm{i}},
$$

where $H=$ breadth of responsiveness, $K$ is a scaling constant (1.661 for four stimuli), and $p_{i}$ is the proportional response to each of $n$ stimuli. The $p_{i}$ for each cell are derived by converting the response profile of that cell to a proportional profile, the response to each stimulus being expressed as a proportion of the total current produced by all four stimuli. This measure takes the relative current magnitude (within a cell) into account in determining the breadth of responsiveness of the cell without imposing a response criterion beyond the minimum of $5 \mathrm{pA}$. In other words, this measure does not simply depend on whether a response occurs, but on the relative magnitude of the response to each stimulus (Smith and Travers, 1979).

Profiles of sensitivity for each cell were constructed by converting the current response of each cell to a relative (to the maximum current) response. Two multivariate procedures were used to investigate the underlying similarities and differences in these response profiles. First, a hierarchical cluster analysis was used to determine the extent to which the various response profiles fall into meaningful clusters (Everitt, 1980; Bieber and Smith, 1986). The clustering program (SPSS for Windows, version 9) processed the cell profiles based on a matrix of the Pearson correlation coefficients between all possible pairs of profiles and amalgamated the cells sequentially into the cluster solution using the average
Table 1. Responses (in picoamperes) to four basic stimuli in 45 taste cells of the fungiform papillae

\begin{tabular}{|c|c|c|c|c|c|}
\hline Cell\# & $\begin{array}{l}0.1 \mathrm{M} \\
\text { sucrose }\end{array}$ & $\begin{array}{l}0.032 \mathrm{M} \\
\mathrm{NaCl}\end{array}$ & $\begin{array}{l}3.2 \mathrm{~mm} \\
\mathrm{HCl}\end{array}$ & $\begin{array}{l}3.2 \mathrm{mM} \\
\mathrm{QHCl}\end{array}$ & $n^{a}$ \\
\hline 33 & - & - & -10 & - & 1 \\
\hline 34 & - & - & - & 15 & 1 \\
\hline 35 & - & - & - & - & 0 \\
\hline 36 & 18 & - & - & - & 1 \\
\hline 37 & - & -10 & -30 & - & 2 \\
\hline 38 & - & - & - & - & 0 \\
\hline 39 & 20 & -20 & -20 & 20 & 4 \\
\hline 41 & 10 & - & - & - & 1 \\
\hline 42 & - & -20 & -8 & 15 & 3 \\
\hline 44 & - & - & -5 & - & 1 \\
\hline 45 & 18 & - & - & - & 1 \\
\hline 46 & 10 & -15 & - & - & 2 \\
\hline 47 & 20 & - & - & - & 1 \\
\hline 48 & - & -12 & - & 15 & 2 \\
\hline 50 & 16 & - & - & - & 1 \\
\hline 53 & - & - & -30 & 25 & 2 \\
\hline 54 & - & -10 & -10 & - & 2 \\
\hline 59 & 10 & - & -8 & - & 2 \\
\hline 60 & 50 & - & -10 & 10 & 3 \\
\hline 61 & 15 & - & -15 & 20 & 3 \\
\hline 62 & 90 & - & - & - & 1 \\
\hline 66 & 70 & -40 & - & - & 2 \\
\hline 68 & - & -10 & - & - & 1 \\
\hline 70 & - & -10 & - & - & 1 \\
\hline 73 & 5 & - & - & - & 1 \\
\hline 74 & 5 & -5 & - & 8 & 3 \\
\hline 81 & 45 & -25 & - & 5 & 3 \\
\hline 83 & 13 & -5 & - & - & 2 \\
\hline 85 & 10 & -8 & -40 & 10 & 4 \\
\hline 86 & 45 & - & -15 & - & 2 \\
\hline 87 & - & - & -15 & 25 & 2 \\
\hline 88 & 50 & - & -30 & 24 & 3 \\
\hline 89 & 20 & - & - & - & 1 \\
\hline 90 & 10 & -5 & -15 & 5 & 4 \\
\hline 91 & - & -5 & - & 13 & 2 \\
\hline 93 & 8 & -13 & - & - & 2 \\
\hline 95 & 5 & -14 & - & 5 & 3 \\
\hline 96 & 13 & -13 & - & 10 & 3 \\
\hline 97 & 33 & -8 & -15 & 8 & 4 \\
\hline 98 & - & -8 & - & 8 & 2 \\
\hline 99 & 5 & -8 & -10 & - & 3 \\
\hline 100 & 28 & - & -25 & - & 2 \\
\hline 101 & 25 & -40 & - & 5 & 3 \\
\hline 102 & - & -15 & -6 & 5 & 3 \\
\hline 103 & - & -14 & - & 5 & 2 \\
\hline$n^{b}$ & 28 & 24 & 19 & 21 & 92 \\
\hline$P^{c}$ & 0.622 & 0.533 & 0.422 & 0.467 & \\
\hline
\end{tabular}

$\overline{{ }^{a} \text { Number of responses in each cell; }{ }^{b} \text { number of cells responding to each stimulus; }}$ ${ }^{c}$ proportion of cells responding to each stimulus.

linkage method. The underlying structure of these data were further examined with multidimensional scaling (MDS) (Alscal, SPSS for Windows, version 9). For this analysis, the matrix of correlation coefficients among the response profiles of all possible pairs of cells was used as the input to produce a two-dimensional representation of the differences among the profiles. The MDS program places the cells into a spatial arrangement that reflects the correlations among them. The combination 


\begin{tabular}{|c|c|c|c|c|c|}
\hline Cell\# & $\begin{array}{l}0.1 \mathrm{M} \\
\text { sucrose }\end{array}$ & $\begin{array}{l}0.032 \mathrm{M} \\
\mathrm{NaCl}\end{array}$ & $\begin{array}{l}3.2 \mathrm{~mm} \\
\mathrm{HCl}\end{array}$ & $\begin{array}{l}3.2 \mathrm{~mm} \\
\mathrm{QHCl}\end{array}$ & $n^{a}$ \\
\hline 1 & - & - & -8 & - & 1 \\
\hline 2 & - & - & - & - & 0 \\
\hline 3 & 15 & - & - & - & 1 \\
\hline 4 & 40 & -10 & -10 & 10 & 4 \\
\hline 5 & - & -10 & - & 10 & 2 \\
\hline 6 & 25 & - & - & 15 & 2 \\
\hline 7 & 13 & -10 & -8 & - & 3 \\
\hline 8 & - & -5 & - & 10 & 2 \\
\hline 9 & - & - & -10 & - & 1 \\
\hline 10 & 15 & -35 & -10 & 15 & 4 \\
\hline 11 & 20 & -25 & -50 & - & 3 \\
\hline 12 & 50 & -15 & -50 & - & 3 \\
\hline 13 & 25 & -10 & - & - & 2 \\
\hline 14 & 40 & - & -10 & - & 2 \\
\hline 15 & 35 & -30 & -10 & 10 & 4 \\
\hline 16 & 25 & -25 & -20 & 30 & 4 \\
\hline 17 & 50 & - & -50 & 20 & 3 \\
\hline$n^{b}$ & 12 & 10 & 11 & 8 & 41 \\
\hline$P^{c}$ & 0.706 & 0.588 & 0.647 & 0.471 & \\
\hline
\end{tabular}

$\overline{{ }^{a} \text { Number of responses in each cell; }{ }^{b} \text { number of cells responding to each stimulus; }}$ ${ }^{c}$ proportion of cells responding to each stimulus.

of these two multivariate procedures provides a view of the similarities (clustering) and dissimilarities (MDS) among the response profiles (Bieber and Smith, 1986), as has been frequently done for responses of gustatory afferent neurons (Frank et al., 1988).

\section{RESULTS}

\section{Basic response properties of taste cells in situ}

We recorded stimulus-induced responses from 120 taste receptor cells maintained in taste buds in the intact epithelium of the anterior tongue $(n=103)$ and soft palate $(n=17)$ using the whole-cell patch-clamp configuration. With the pipette containing $140 \mathrm{~mm} \mathrm{KCl}$ and the bath Tyrode, cells of the fungiform papillae had an input slope resistance between 0.59 and $2.11 \mathrm{G} \Omega$ [mean, $1.28 \pm 0.37(\mathrm{SD}) \mathrm{G} \Omega]$ and a zero current potential ranging between -71 and $-29 \mathrm{mV}$ (mean, $-53.4 \pm 10.2 \mathrm{mV}$ ). These values are in the same range as those recorded from dissociated taste cells from rat fungiform (Béhé et al., 1990b; Gilbertson et al., 1997) or vallate (Herness and Sun, 1995) papillae. Similar values were obtained from the 17 cells in the soft palate. Zero current potentials for palatal taste cells ranged from -67 to -39 $\mathrm{mV}[$ mean, $-52.4 \pm 9.3(\mathrm{SD}) \mathrm{mV}$ ] and input resistance ranged from 0.78 to $2.49 \mathrm{G} \Omega$ (mean, $1.64 \pm 0.51 \mathrm{G} \Omega$ ). All of the recorded cells showed voltage-activated outward $\left(\mathrm{K}^{+}\right)$currents and a subset of these additionally exhibited transient voltage-activated inward $\left(\mathrm{Na}^{+}\right)$currents $(29$ of $120=24.2 \%)$.

The currents evoked in two cells recorded in the MU chamber in response to a voltage-step protocol are shown in Figure 3. These cells were held at $-80 \mathrm{mV}$ and stepped to $+40 \mathrm{mV}$ in 10 $\mathrm{mV}$ increments. The cell in $A$ showed only voltage-activated outward currents, which were reduced $(B)$ by the addition of the $\mathrm{K}^{+}$channel blockers 4-aminopyridine (4-AP; $10 \mathrm{~mm}$ ) and tetraethylammonium chloride (TEA; $10 \mathrm{~mm}$ ) to the serosal bath. The cell in $C$ showed both inward and outward currents in response to the voltage protocol; the inward currents were reduced $(D)$ by the $\mathrm{Na}^{+}$channel blocker tetrodotoxin (TTX; $\left.1 \mu \mathrm{M}\right)$.

\section{Taste responses: current-clamp experiments}

Experiments on taste responses were conducted in one of two ways. In an early series of experiments, taste cells of the fungiform papillae were held near their resting potentials in currentclamp mode (i.e., zero current level), and tastant-induced changes in membrane potential were recorded. A cell was considered responsive to one of the taste stimuli if it induced a reversible change in membrane potential that was at least $5 \mathrm{mV}$ from resting levels and time-locked to the stimulus flow; such a change was a clearly discernable response. Figure 4 shows taste responses of two cells in this configuration. One of these cells (Fig. 4A) was tested with sucrose, $\mathrm{NaCl}$ and $\mathrm{KCl}$ and showed a depolarization only to sucrose. The other cell (Fig. 4B) responded to $\mathrm{NaCl}, \mathrm{KCl}$, citric acid, and $\mathrm{HCl}$, but not to sucrose; it was not tested with QHCl. Although the response of this cell to $\mathrm{NaCl}$ had a much more sudden onset than those to $\mathrm{KCl}$ and the two acids, this was not a consistent observation across cells. The weakest response (to $\mathrm{HCl}$ ) was two or three times the response criterion of $5 \mathrm{mV}$. In these current-clamp experiments, all responses were depolarizing in nature, no cells responded to any of the six stimuli with a hyperpolarizing response.

Data were obtained from 21 cells in current-clamp mode. Because we were unable to hold any of these cells long enough to apply all six stimuli, it was not possible to determine precisely the breadth of their chemical sensitivities. Some of the cells were tested with only one or two stimuli. Nevertheless, 11 of the 21 cells $(52.4 \%)$ responded to more than one stimulus, and 5 $(23.8 \%)$ responded to three or four stimuli. Three cells were tested with both of the acids (citric acid and $\mathrm{HCl}$ ), which elicited similar responses in each cell (see also the acid responses in Fig. $4 B$ ). In this part of the study, we were unable to record from any cells during application of all six stimuli, but these data are combined with the voltage-clamp data presented below to deter-

\begin{tabular}{|c|c|c|c|c|c|}
\hline $\begin{array}{l}\text { Combination } \\
(x, y)\end{array}$ & $\begin{array}{l}\text { No. cells } \\
\text { tested }\end{array}$ & $\left(p_{\mathrm{x}}\right)\left(p_{\mathrm{y}}\right)^{a}$ & Predicted & Observed & $P^{b}$ \\
\hline $\mathrm{S}, \mathrm{N}$ & 84 & $(0.643)(0.488)=0.314$ & 26.4 & 25 & $>0.65$ \\
\hline $\mathrm{S}, \mathrm{H}$ & 71 & $(0.648)(0.507)=0.329$ & 23.3 & 23 & $>1.00$ \\
\hline$S, Q$ & 71 & $(0.634)(0.493)=0.313$ & 22.2 & 21 & $>0.63$ \\
\hline $\mathrm{N}, \mathrm{H}$ & 72 & $(0.542)(0.514)=0.279$ & 20.1 & 21 & $>0.81$ \\
\hline $\mathrm{N}, \mathrm{Q}$ & 73 & $(0.479)(0.507)=0.243$ & 17.8 & 22 & $>0.06$ \\
\hline $\mathrm{H}, \mathrm{Q}$ & 72 & $(0.514)(0.458)=0.235$ & 16.9 & 19 & $>0.36$ \\
\hline
\end{tabular}

${ }^{a}$ Proportion of tested cells responding to each member of the pair; response criterion: $\geq 5 \mathrm{pA}$ or $5 \mathrm{mV} ;{ }^{b}$ statistical difference tested using the Fisher exact probability test (SigmaStat version 2.0). S, Sucrose; N, NaCl; H, HCl; Q, QHCl. 


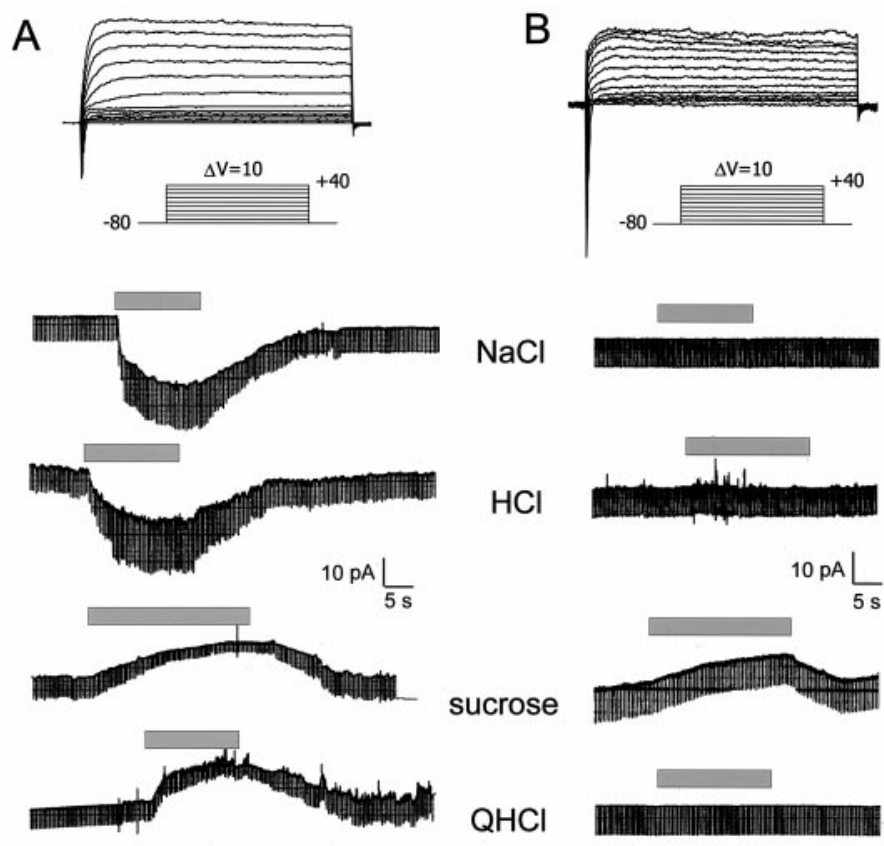

Figure 5. Voltage-clamp responses of taste cells to stimuli representing the four basic taste qualities. Top traces show the voltage-activated currents in two cells in response to voltage steps from -80 to $+40 \mathrm{mV}$ from a holding potential of $-80 \mathrm{mV}$. These cells displayed both transient inward $\mathrm{Na}^{+}$currents and sustained outward $\mathrm{K}^{+}$currents; the difference between the voltage-activated currents shown in these cells is within normal variation. The bottom four sets of traces show the current responses to application of taste stimuli $(0.032 \mathrm{M} \mathrm{NaCl}, 3.2 \mathrm{~mm} \mathrm{HCl}, 0.1 \mathrm{M}$ sucrose, and $3.2 \mathrm{~mm} \mathrm{QHCl}$ ); the cells were held at their resting potential. Brief downward deflections in these records are the current responses to $10 \mathrm{mV}$ hyperpolarizations used to monitor changes in conductance (e.g., larger deflections indicate a conductance increase and vice versa). The cell shown in $A$ responded to all four stimuli, whereas that shown in $B$ responded to only sucrose.

mine the overall distributions of responsiveness to pairs of stimuli (Table 3).

\section{Taste responses: voltage-clamp studies}

Because we had better success using voltage clamp to record stimulus-induced changes in whole-cell currents, the majority of experiments were performed using the voltage-clamp recording mode. Similar to the results using current-clamp recording, we found that cells displayed a range of chemical sensitivities. Figure 5 shows current responses of two taste cells of the fungiform papillae to stimuli representing the four basic taste qualities. In these experiments, the criterion for the occurrence of a response was a reversible change in current $\geq 5 \mathrm{pA}$ from resting current level; the response to sucrose in Figure $5 B$ was about twice this criterion. When reversible and time-locked to the stimulus application (as in Fig. 5), a 5 pA current change is an unmistakable response. Some analyses were also conducted using a more stringent $(\geq 10 \mathrm{pA})$ criterion. Many of the cells responded to more than one class of taste stimulus; the cell depicted in Figure $5 A$ responded to all four of the basic taste stimuli. Responses to the six stimuli used in these experiments took one of two forms. Cells responded to $\mathrm{NaCl}, \mathrm{HCl}, \mathrm{KCl}$, and $\mathrm{NH}_{4} \mathrm{Cl}$ with a conductance increase (increase in inward current), whereas responses to sucrose and $\mathrm{QHCl}$ showed a decrease in cellular conductance (decrease in outward current), as seen in Figure $5 \mathrm{~A}$. Both response types would lead to depolarization of a taste cell, consis- tent with the responses recorded under current clamp (Fig. 4). These response types were consistent across all cells of fungiform papillae and palate, as may be seen below in Tables 1 and 2. Many cells showed greater specificity, such as the sucrose-responsive cell in Figure $5 B$ (compare Fig. $4 A$ ), which did not respond to $\mathrm{NaCl}, \mathrm{HCl}$, or $\mathrm{QHCl}$.

Responses to taste stimulation were recorded in voltage-clamp mode from 82 cells of the fungiform papillae and 17 of the soft palate. Of these 99 cells, $67(67.7 \%)$ responded ( $\geq 5 \mathrm{pA})$ to more than one stimulus; if the criterion for a response was set at a more stringent level ( $\geq 10 \mathrm{pA})$, then 87 of these cells responded to at least one stimulus, and 51 of these $87(58.6 \%)$ to more than one. Over all 120 cells (including the 21 recorded in current-clamp mode), $78(65.0 \%)$ responded ( $\geq 5 \mathrm{pA}$ or $5 \mathrm{mV}$ ) to more than one stimulus, although it should be noted that a number of these cells were only tested with one or two stimuli. Responses to different stimuli in the same cell were often similarly robust. Across the 67 cells recorded in voltage-clamp mode that responded to more than one stimulus, the response to the second most effective stimulus averaged $63.9 \%$ of the current change induced by the most effective (Fig. 5A, Tables 1, 2).

Across both the fungiform papillae and palate, 62 cells were tested with each of the four basic stimuli (sucrose, $\mathrm{NaCl}, \mathrm{HCl}$, and $\mathrm{QHCl}$ ); 24 of the fungiform cells were also tested with $\mathrm{KCl}$ and $\mathrm{NH}_{4} \mathrm{Cl}$. Of the 62 cells tested with the four basic stimuli, 59 responded to at least one of them. Of these 59 cells, $16(27.1 \%)$ responded to only one of the four, whereas the remaining cells responded to two or more stimuli (43 cells; $72.9 \%$ ). Two of the cells responding to none of these four stimuli responded to $\mathrm{KCl}$ and/or $\mathrm{NH}_{4} \mathrm{Cl}$; the third was not tested with these compounds. Responses to sucrose, $\mathrm{NaCl}, \mathrm{HCl}$ and $\mathrm{QHCl}$ in the 45 cells of the fungiform papillae are shown in Table 1, and those of the 17 palatal cells are depicted in Table 2. These tables also depict the proportion $(P)$ of cells in these samples responding to each stimulus. Altogether, there were 92 reliable responses (i.e., reversible responses $\geq 5 \mathrm{pA}$ ) evoked in the 43 responsive fungiform cells by these four stimuli, averaging 2.14 responses per cell. The mean response to all second, third, and fourth responses in these 43 cells was $56.0 \%$ of the magnitude of the response to the most effective stimulus (Table 1).

The responses of the 17 cells of the soft palate are shown in Table 2. Within the 16 cells responsive to at least one of the four basic stimuli, there were 41 responses ( $\geq 5 \mathrm{pA}$ ), averaging 2.56 responses per cell. The mean response to all second, third, and fourth responses in these 16 cells was $53.6 \%$ of the magnitude of the response to the most effective stimulus (Table 2).

To determine the breadth of sensitivity of the cells that were tested with all four stimuli, their breadth of tuning $(H)$ was determined using the entropy measure (Smith and Travers, 1979). Over all 59 responsive cells, the mean $H$ value was $0.462 \pm 0.042$ (SEM). This value is smaller than what has been reported for fibers of the rat chorda tympani nerve (0.561) (Travers, 1993) or nucleus of the solitary tract (0.790) (Giza and Scott, 1991). For the 43 cells of the fungiform papillae that were responsive to at least one of the four basic stimuli, the mean entropy was $0.429 \pm$ 0.049 . The breadth of tuning of the 16 palatal cells $(0.552 \pm 0.083)$ was not significantly different from that of the cells of the fungiform papillae $(t=1.302 ; \mathrm{df}=57 ; p>0.1)$.

Among the 59 responsive cells tested with all four stimuli in both the fungiform papillae and palate, 13 exhibited both inward $\left(\mathrm{Na}^{+}\right)$and outward $\left(\mathrm{K}^{+}\right)$currents in response to the voltage-step protocol (Figs. $3 C, 5 A, B$ ). The cells with both $\mathrm{Na}^{+}$and $\mathrm{K}^{+}$ 
currents had significantly greater breadth of responsiveness [mean $H, 0.660 \pm 0.078(\mathrm{SEM}) ; n=13$ ] than those with only $\mathrm{K}^{+}$ currents (mean, $0.406 \pm 0.047 ; n=46$; two-tailed $t$ test; $t=2.614$; df $=57 ; p<0.02)$.

\section{Taste responses: independent sensitivities}

Among the four basic stimuli, as many as 84 cells and no fewer than 71 cells were tested with two members of each possible pair of stimuli. The distributions of sensitivities to pairs of the four basic stimuli are shown in Table 3. Here, all data for each pair of tastants $(x$ and $y)$, from both the voltage-clamp and the earlier current-clamp experiments were combined to assess the relative distributions of sensitivities. The number of cells tested with each member of the pair is given in Table 3, along with the proportions of cells responding to each member of the pair $\left(p_{x}\right.$ and $\left.p_{y}\right)$, and the number of predicted and observed responses to both members of the pair. If the distributions of these sensitivities were not independent, we would expect that certain combinations would occur more or less often than predicted. For each possible pair of the four basic stimuli, however, the number of cells showing sensitivity to both members of the pair is no different than predicted by chance (all $P \mathrm{~s}>0.05$; Fisher exact probability test); i.e., the number of cells responding to both is predicted by the product of the probabilities of the response to each member of the pair. Increasing the response criterion to $\geq 10 \mathrm{pA}$ resulted in fewer responses (as can be appreciated by examination of Tables 1 and 2), but an analysis of the sensitivities to pairs of the four stimuli still shows them to be independent of one another, except for sucrose and $\mathrm{HCl}$, which occurred slightly more often than expected by chance. With a response criterion of $\geq 10 \mathrm{pA}$, sensitivities to sucrose and $\mathrm{HCl}$ occurred together in 20 cells, although an independent distribution would predict only 15.8 cells with joint sensitivity to these two stimuli (Fisher exact probability test, $p=0.042$ ). All other pairs of sensitivities were not different from chance occurrence, even with a response criterion of $\geq 10 \mathrm{pA}$. Thus, using a more stringent criterion does not reduce the number of joint occurrences among these sensitivities.

Analysis of the distributions of the responses to $\mathrm{KCl}$ and $\mathrm{NH}_{4} \mathrm{Cl}$ also suggest stochastic independence between these sensitivities and among $\mathrm{KCl}, \mathrm{NH}_{4} \mathrm{Cl}$, and the other four stimuli. For example, $\mathrm{KCl}$ and $\mathrm{NH}_{4} \mathrm{Cl}$ were tested together on 35 receptor cells (data not shown). $\mathrm{KCl}$ produced a reversible change in membrane current in 18 cells, $\mathrm{NH}_{4} \mathrm{Cl}$ in 16 cells, and both produced responses in 11 of the same cells. An independent distribution of these sensitivities predicts that 8.2 cells should respond to both; this difference was not statistically significant (Fisher exact probability test, $p=0.729$ ). Similarly, $\mathrm{KCl}$ and $\mathrm{NH}_{4} \mathrm{Cl}$ responses were not associated with responses to sucrose, $\mathrm{NaCl}, \mathrm{HCl}$, or $\mathrm{QHCl}$ to a greater or lesser extent than predicted by chance. In some instances (e.g., $\mathrm{NaCl}$ and $\mathrm{KCl}$ ), as many as 48 cells and no fewer than 30 cells $\left(\mathrm{NH}_{4} \mathrm{Cl}\right.$ and $\left.\mathrm{HCl}\right)$ were tested with pairs of these stimuli.

\section{Taste responses: multivariate analyses}

For the 59 cells (of both the fungiform papillae and palate) responding to at least one of the four basic stimuli, the magnitudes of the current responses (shown in Tables 1 and 2) were converted to proportions of the maximum response for each cell. These relative current values were then entered into a hierarchical cluster analysis (SPSS for Windows, version 9) to examine the similarities in their response patterns to the four stimuli. The results of this analysis are depicted in the dendrogram of Figure

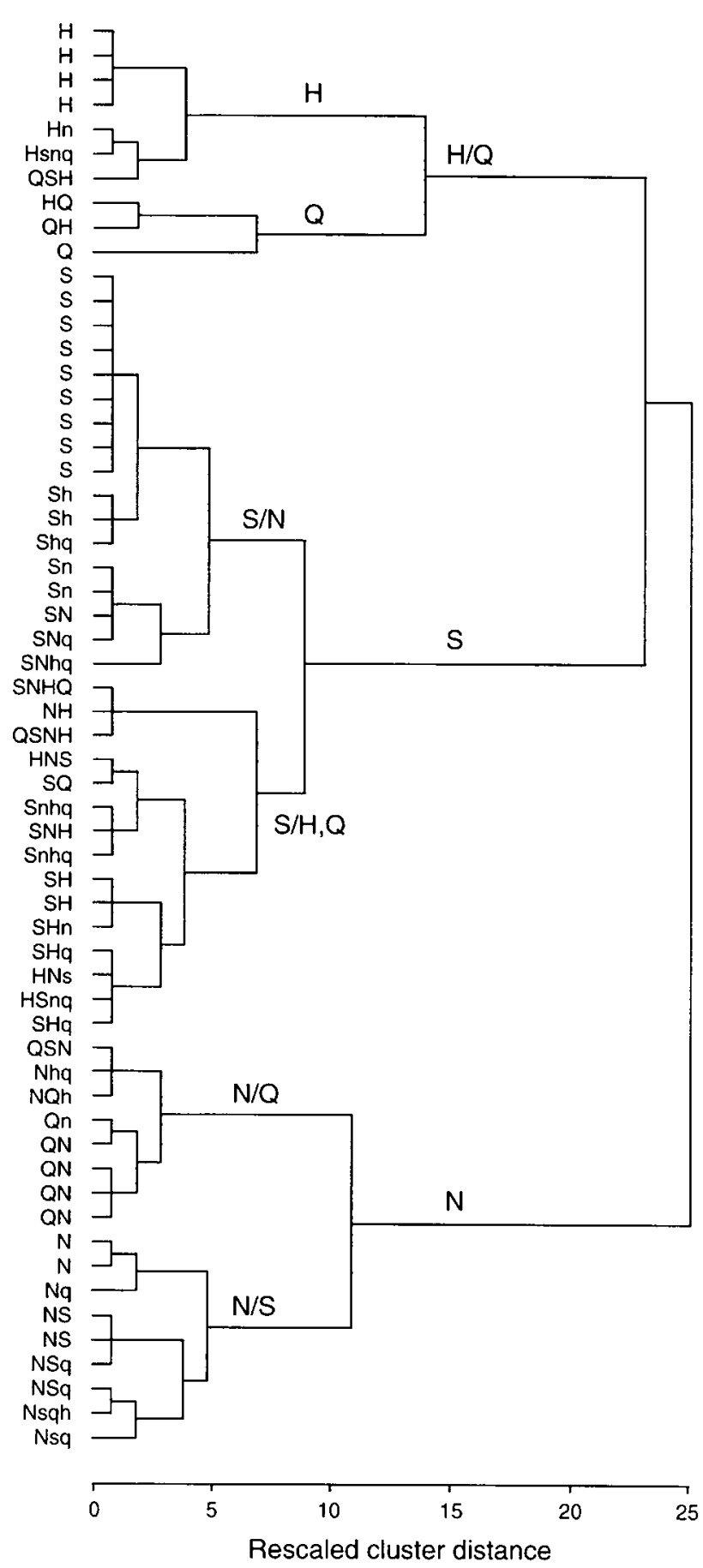

Figure 6. Cluster dendrogram showing the relationships among response profiles of rat taste receptor cells. Input was the normalized (to the maximum response) current produced in each cell by the four stimuli. The response profile of each cell is indicated on the left. Capital letters indicate the stimulus producing the maximum response (shown first) and all others with responses $\geq 50 \%$ of maximum. Lowercase letters indicate responses $<50 \%$ of the maximum; the order of the letters indicates the relative magnitude of the response to each stimulus. The three clusters, which are not sharply differentiated, are labeled $\mathrm{H} / \mathrm{Q}, \mathrm{S}$, and $\mathrm{N}$ according to which stimulus was common to all members of the group (but not necessarily the best stimulus for every member of the group). The common stimuli for two subclusters of each major cluster are also indicated on the dendrogram. 
6 , which shows the ordering of the cells from those with the most similar response profiles to those that are least similar in their responses. Along the ordinate, the response profiles are indicated by letters [sucrose (S), $\mathrm{NaCl}(\mathrm{N}), \mathrm{HCl}(\mathrm{H})$, and $\mathrm{QHCl}(\mathrm{Q})$ ] arranged from left to right in order of response magnitude within the cell. Capital letters indicate either the maximum response (on the left) or other responses that were at least half the value of the maximum. Responses smaller than half the maximum are shown as lowercase letters. The cluster analysis arranged the cells into three major clusters of response patterns, indicated by the cluster distances depicted by the horizontal and vertical lines. These three groups, labeled H/Q, S, and N, were characterized by their common response to one or more of the four basic stimuli. For example, all the cells in the $\mathrm{S}$ group (except one) responded to sucrose, although many of these cells also responded to other stimuli; sucrose often produced responses also in the other groups of cells (and was even the maximum response for some other cells). The other two groups ( $\mathrm{H} / \mathrm{Q}$ and $\mathrm{N})$ were characterized by their common responses to $\mathrm{HCl}$ and/or $\mathrm{QHCl}$ and $\mathrm{NaCl}$, respectively. Although each of these groups is characterized by its common response to one or two stimuli, that stimulus did not necessarily produce the best (maximum) response in each member of the group. Thus, although the responses to these four stimuli are independent of one another, there is some order to their patterns of sensitivity when response magnitude is considered.

To further examine the relationships among the response profiles of these cells, the relative current responses were analyzed using MDS. For this analysis, the matrix of correlation coefficients among the response profiles of all possible pairs of cells was used as the data for an MDS analysis, the results of which are shown in Figure 7. This two-dimensional solution accounted for $95.4 \%$ of the data variance. The proximity of cells in this figure depicts the similarity in their response profiles; symbols represent different subclusters in the dendrogram of Figure 6, and dashed lines indicate the three major clusters. That is, triangles represent the cells of the H/Q cluster, with the H subcluster shown as gray and the $\mathrm{Q}$ as black triangles. The cells of the $\mathrm{N}$ cluster are depicted as squares, with the open squares the N/S subcluster and the black squares the N/Q subcluster. The cells of the S cluster are shown as circles, with the open circles the $\mathrm{S} / \mathrm{N}$ subcluster and the gray circles the $\mathrm{S} / \mathrm{H}, \mathrm{Q}$ subcluster. The labels $\mathrm{S}, \mathrm{N}, \mathrm{H}$, and $\mathrm{Q}$ indicate the cells responding exclusively to one of the four stimuli, which are maximally separated within this space. The position of these cells in this two-dimensional space reflects the similarities and differences in their response profiles, which directly reflects the results of the hierarchical cluster analysis shown in Figure 6. The one exception is the gray circle shown in the H/Q cluster, which was a cell of the $\mathrm{S}$ cluster that responded strongly to both $\mathrm{NaCl}$ and $\mathrm{HCl}$; it was the only cell of its kind. The positions of these subclusters in multidimensional space indicate that the profiles of sensitivity are representative of very loosely defined cell types. That is, although there are orderly groupings of these receptor cells on the basis of their response profiles, the distinctions among these groups are not striking, with almost all combinations of sensitivities occurring together across this sample of cells. Similar analyses at higher levels of the rat gustatory system also show relatively loosely defined clusters of cells (Chang and Scott, 1984; Giza and Scott, 1991).

Across the 59 cells responding to at least one of the four basic stimuli, each stimulus elicited a unique pattern of responses, as shown in Figure 8. In this figure, responses of each cell that

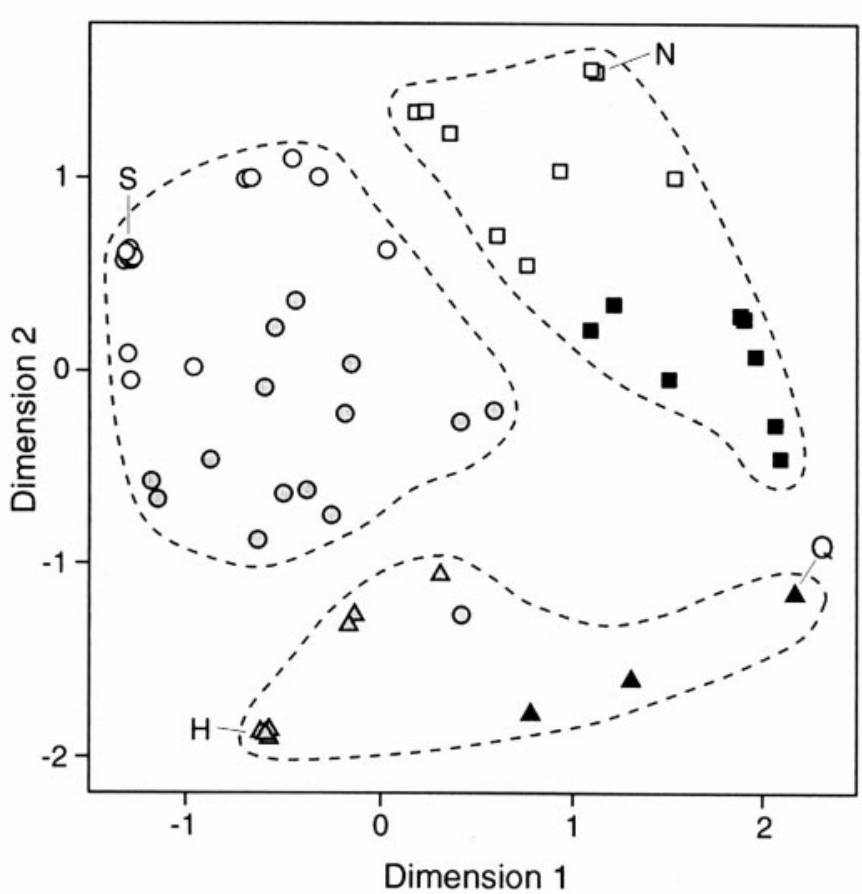

Figure 7. Two-dimensional space showing the relationships among response profiles of rat taste receptor cells, derived from multidimensional scaling. Input was the complete correlation matrix among the normalized currents produced in each cell by the four stimuli. The three clusters of cells identified by the hierarchical cluster analysis of Figure 6 are delineated by dashed lines and also indicated by different symbols: H/Q cluster, triangles; $\mathrm{S}$ cluster, circles, and $\mathrm{N}$ cluster, squares. These three groups are further delineated in the figure by symbol shading, which depicts the subclusters shown in Figure 6 (see Results). The letters S, N, H, and Q indicate the positions of the cells responding exclusively to each one of the four stimuli; all other cells were more broadly responsive, as indicated in the dendrogram of Figure 6.

reached the $5 \mathrm{pA}$ criterion are shown as relative (to the maximum response) current; the cells are arranged in order of the results of the hierarchical cluster analysis (Fig. 6). That is, cells on the extreme left are those at the top of the dendrogram of Figure 6, and those at the extreme right are those at the bottom of the dendrogram. Cells recorded from the fungiform papillae are shown as shaded bars and those from the palate as open bars. As noted above, most of these 59 cells $(72.9 \%)$ responded to more than one of these stimuli, but there is a unique pattern of activity generated by each stimulus across these cells. Many of these cells responded maximally to more than one stimulus (such as the cell shown in Fig. 5A). Differential input from these broadly tuned receptor cells serves to establish unique across-fiber patterns in the chorda tympani or greater superficial petrosal nerves; such patterns may underlie the ability of rats to discriminate among these basic tastes (Pfaffmann, 1959; Erickson et al., 1965; Erickson, 1968; Smith and St. John, 1999).

\section{DISCUSSION}

\section{Apical chemical stimulation of taste receptor cells}

Recent studies of taste receptor cell physiology have used patchclamp recording methods on isolated cells (Avenet and Lindemann, 1987; Akabas et al., 1988; Kinnamon et al., 1988; Gilbertson et al., 1993; Herness and Sun, 1995; Chen et al., 1996; Cummings et al., 1996), but the range of gustatory stimuli that can be applied to isolated cells is restricted. Although other labora- 

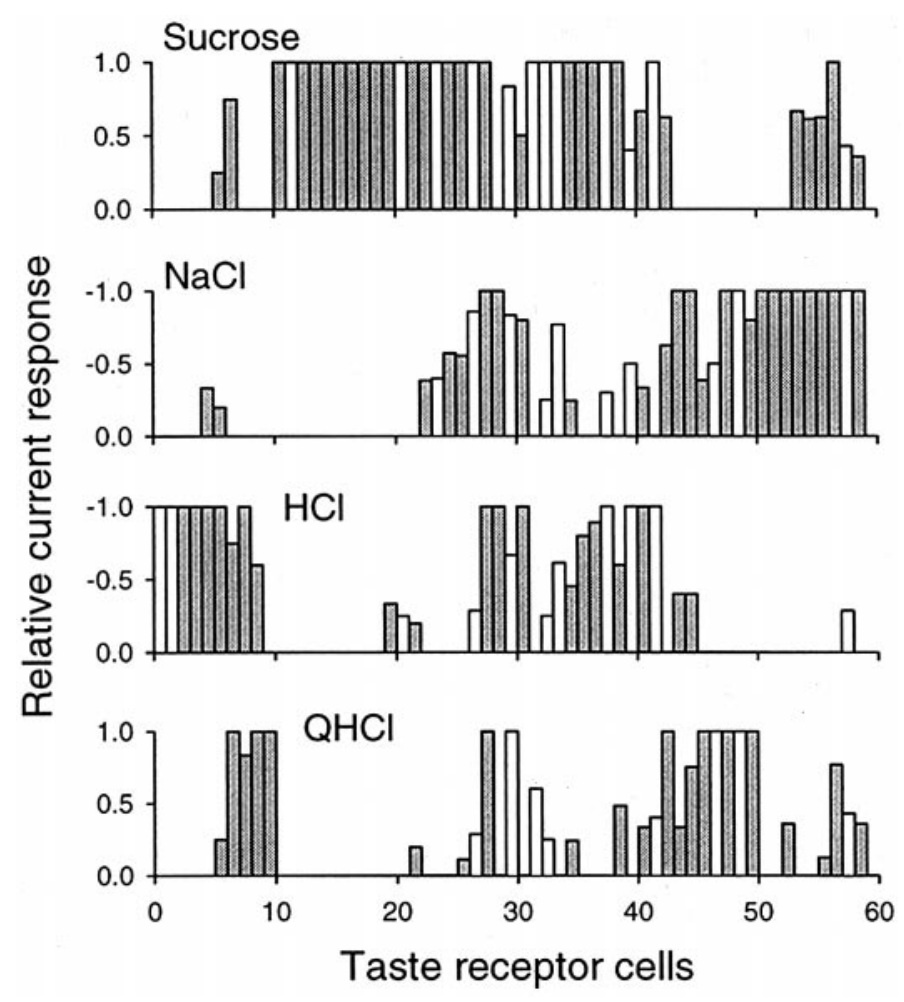

Figure 8. Response patterns to four basic taste stimuli evoked across 59 rat taste receptor cells of the fungiform papillae and palate. Responses above criterion (a reversible current $\geq 5 \mathrm{pA}$ ) were converted to proportions of the maximum response for each cell (actual current values are given in Tables 1 and 2). The cells are arranged along the abscissa in the order given by the hierarchical cluster analysis of Figure 6 . Thus, the leftmost cells (cells 1-10) are characterized by their common response to $\mathrm{HCl}$ and/or $\mathrm{QHCl}$, the next group of cells (11-42) all (except one) responded to sucrose, and the last group (43-59) to NaCl. Many of these cells responded maximally to several of the stimuli. Sixteen cells were responsive to only one of the four stimuli; the other 43 cells responded to more than one. Although these receptor cells are largely responsive to more than one stimulus, the patterns of activity across the cells provides differential input to first-order afferent neurons that can serve as a substrate for gustatory discrimination.

tories have used an intact epithelial preparation (Roper and McBride, 1989; Béhé et al., 1990a; Furue and Yoshii, 1997, 1998; Ohtubo et al., 2001), there has been limited success in applying a range of stimuli to a sizeable number of cells. For example, Furue and Yoshii (1997) recorded from only five cells in mouse fungiform taste buds that were responsive to one or more of three taste stimuli applied to the apical membrane and Ohtubo et al. (2001) applied only $\mathrm{NaCl}$ or a taste mixture. The present data are the first to show the distribution of gustatory sensitivities across a large number of mammalian taste receptor cells using patchclamp methods and apically restricted stimuli.

The increased conductance and inward current produced by $\mathrm{NaCl}$ in the present experiment are compatible with its passage through both apically located amiloride-sensitive $\mathrm{Na}^{+}$channels and basolateral ion channels (Boughter and Gilbertson, 1999). Indeed, the rapid depolarization seen to $\mathrm{NaCl}$ in Figure $4 B$ could be caused by the passage of $\mathrm{Na}^{+}$through the amiloride-sensitive channel, although this possibility was not tested nor was this rapid time course consistent across the few cells tested in the currentclamp experiments. The mechanisms underlying the inward current produced by $\mathrm{HCl}$ in these experiments, however, are less clear. Acids have been shown to depolarize mammalian taste cells by proton permeation of apical amiloride-sensitive sodium channels under conditions of low mucosal sodium (Gilbertson et al., 1992, 1993; Harris et al., 1994), which is consistent with the responses seen in the present experiments. However, acids have been shown to block apical $\mathrm{K}^{+}$channels in mudpuppy (Kinnamon et al., 1988) and in mammals a $\mathrm{Cl}^{-}$conductance may also be involved in acid transduction (Miyamoto et al., 1998). Without exception, both $\mathrm{NaCl}$ and $\mathrm{HCl}$ produced inward currents accompanied by increased conductance, suggesting that acids do not depolarize rat taste cells by blocking channels.

In the present experiment, both sucrose and $\mathrm{QHCl}$ decreased an outward conductance. Sucrose and other sweeteners have been shown to block a basolateral $\mathrm{K}^{+}$channel as a consequence of second-messenger activation (Cummings et al., 1996), but the conductance decrease produced by $\mathrm{QHCl}$ in these cells is not so readily explained. If $\mathrm{QHCl}$ stimulates via a gustducin-mediated pathway, one would expect an increased conductance resulting from opening of basolateral cyclic nucleotide-gated channels; activation via the $\mathrm{IP}_{3}$ pathway would also not be expected to produce a decreased membrane conductance (Herness and Gilbertson, 1999). In patch-clamp experiments on isolated mouse taste cells, quinine produced an inward current and increased conductance when the cells were held at negative potentials (Seto et al., 1999), even when quinine was restricted to the apical membrane (Furue and Yoshii, 1998). On the other hand, QHCl has been shown to block an outward $\mathrm{K}^{+}$conductance in isolated rat taste cells (Akabas et al., 1990; Chen and Herness, 1997). However, there is no evidence for apically localized $\mathrm{K}^{+}$channels on mammalian taste cells. The present results show that $\mathrm{QHCl}$ always produces a decrease in outward current in cells held at resting potential, suggesting that either apically applied $\mathrm{QHCl}$ is able to block $\mathrm{K}^{+}$channels or it may lead to a conductance decrease through less frequent opening of a basolateral cyclic nucleotide-gated channel (Yan et al., 2000).

Although there have been a few reports of hyperpolarizing responses to taste stimuli in intracellular studies of mammalian taste cells [Sato and Beidler, 1982 (in rat); Tonosaki and Funakoshi, 1984 (in mouse)], we saw no such responses in either fungiform or palatal taste cells. In these earlier studies, there were fewer hyperpolarizing responses when the cells were adapted to distilled water, as in the present experiments. Most other studies of mammalian taste cells, however, have reported only depolarizing responses (Ozeki and Sato, 1972; Tonosaki and Funakoshi, 1984; Sato and Beidler, 1997).

\section{Multiple gustatory sensitivities}

The data presented here demonstrate that taste receptor cells are often responsive to stimuli representing more than one of the classic four taste qualities (sucrose, $\mathrm{NaCl}, \mathrm{HCl}$, and $\mathrm{QHCl}$ ). Measures of the breadth of tuning show that taste receptor cells are slightly less broadly tuned to these stimuli than fibers of the chorda tympani nerve (Travers, 1993), suggesting some convergence onto first-order neurons. Furthermore, the number of cells responding to each of the six possible pairs of these four stimuli is predictable from an assumption of four sensitivities independently distributed across receptor cells. A similar result has been shown previously for the distribution of sensitivities across single fibers of the rat chorda tympani and glossopharyngeal nerves (Frank and Pfaffmann, 1969). An earlier intracellular recording experiment on rat taste cells (Ozeki and Sato, 1972) also found an independent distribution of sensitivities to sucrose, $\mathrm{NaCl}, \mathrm{HCl}$, 
and QHCl. Independence among sensitivities to several bitter stimuli was reported in a recent calcium imaging study of rat lingual slices (Caicedo and Roper, 2001). These previous data and the present results suggest strongly, on the basis of different recording methods, that taste sensitivities to stimuli representing the human qualities of sweet, salty, sour, and bitter are not restricted to separate, specifically tuned cell types.

This broad responsiveness could result from an overlap in the transduction mechanisms for different classes of stimuli within single receptor cells, as reported in hamster taste cells for sodium salts and acids, which both use the amiloride-sensitive $\mathrm{Na}^{+}$channel (Gilbertson et al., 1992, 1993). Alternatively, multiple receptors and transduction cascades could be present within a single cell (Herness and Gilbertson, 1999) or there could be some form of cell-to-cell communication within the taste bud (Roper, 1993). Recent data showing the coexpression of several members of a family of putative bitter taste receptors in single receptor cells (Adler et al., 2000; Chandrashekar et al., 2000) are not incompatible with the present results, which suggest that these same cells could possibly express other receptors as well. Further molecular studies should be able to provide definitive evidence for the origin of the multiple sensitivities shown in the present experiment. Although it is likely that testing these cells with additional stimuli and a broader range of concentrations would more clearly reveal the extent of this multiple sensitivity than can be seen with only four stimuli, the present results clearly show that these cells are, for the most part, not specific to a single stimulus.

We observed that cells exhibiting voltage-activated $\mathrm{Na}^{+}$currents $(13 / 62,21 \%)$ were significantly more broadly tuned than those with only $\mathrm{K}^{+}$currents. Since the generation of action potentials, which depend on voltage-activated $\mathrm{Na}^{+}$channels, may be necessary for transmitter release (Roper, 1983; Avenet and Lindemann, 1989; Béhé et al., 1990b), it is likely that these broadly tuned cells are more mature than those without $\mathrm{Na}^{+}$ currents. In the mudpuppy, mature cells with apical processes reaching the taste pore show large inward and outward currents, whereas those that have not yet reached the pore have only outward currents (Mackay-Sim et al., 1996). Previous studies of isolated cells in the rat have also shown that only subsets of cells have inward currents, ranging from only $10 \%$ (Akabas et al., 1990) to 50-75\% (Béhé et al., 1990b; Chen et al., 1996).

\section{Information transmission}

At first glance, an independent distribution of gustatory sensitivities seems counterintuitive. What possible advantage could there be to such an arrangement? One possibility lies in the greater capacity of such a system for transmitting information. A basic tenet of information theory is that multicomponent messages convey maximum information only when the individual components are independent (Shannon and Weaver, 1959). This means that sensory systems that encode information by the patterns of activity across broadly tuned neurons are inherently capable of transmitting more information than systems using specifically tuned cells (Pfaff, 1975). In general, greater information capacity means that finer discriminations can be made on the basis of sensory input. Even assuming only four taste qualities, the hundreds of potential gustatory stimuli would be composed of subtle combinations of these four. The known ability of rats to make behavioral discriminations between, for example, the taste of sucrose and maltose (Spector et al., 1997) or QHCl and KCl (St. John and Spector, 1998), depends on a system with subtle dis- criminatory capabilities. Thus, the independent distribution of taste sensitivities across receptor cells and the resulting broadly tuned afferent neurons provide the substrate for an across-neuron pattern code capable of relatively subtle behavioral discriminations (Pfaff, 1975).

An independent distribution of taste sensitivities raises interesting questions about the synaptic relationships between taste receptor cells and first-order neurons. Input from the taste receptors must generate a unique, recognizable pattern of activity in the CNS. However, taste receptor cells turn over with a life span of 9 or $10 \mathrm{~d}$ (Beidler and Smallman, 1965; Farbman, 1980), necessitating the continual formation of new synaptic connections between emerging receptor cells and afferent nerve fibers. To maintain a constant neural code for sensory quality, either the nerve fibers must impart the sensitivities to the developing receptor cells or they must seek out particular types of cells with which to make synaptic contact. Cross-reinnervation experiments, in which the IXth nerve is made to reinnervate the anterior tongue, demonstrate that neither the gustatory sensitivities nor the molecular phenotypes of taste cells in fungiform papillae are influenced by the innervating nerve (Oakley, 1967; Smith et al., 1999). In contrast, the several branches of a peripheral axon that innervate different fungiform papillae have been shown to have similar gustatory sensitivities (Oakley, 1975). Taken together, these data imply that gustatory afferent fibers are guided to particular taste receptor cells during cell turnover and synaptogenesis. A major challenge is to determine the molecular signals that underlie the anatomical relationships between taste receptor cells and their innervating axons.

\section{REFERENCES}

Adler E, Hoon MA, Mueller KL, Chandrashekar J, Ryba NJP, Zuker CS (2000) A novel family of mammalian taste receptors. Cell 100:693-702. Akabas MH, Dodd J, Al-Awqati Q (1988) A bitter substance induces a rise in intracellular calcium in a subpopulation of rat taste cells. Science 242:1047-1050

Akabas MH, Dodd J, Al-Awqati Q (1990) Identification of electrophysiologically distinct subpopulations of rat taste cells. J Membr Biol 114:71-78.

Avenet P, Lindemann B (1987) Patch-clamp study of isolated taste receptor cells of the frog. J Membr Biol 97:223-240.

Avenet P, Lindemann B (1989) Perspectives of taste reception. J Membrane Biol 112:1-8.

Béhé P, DeSimone JA, Avenet P, Lindemann B (1990a) Patch-clamp recording from taste buds of maintained epithelial polarity: a novel approach. In: ISOT X. Proceedings of the Tenth International Symposium on Olfaction and Taste (Doving KB, ed), p 271. Oslo: Graphic Communication System A/S.

Béhé P, DeSimone JA, Avenet P, Lindemann B (1990b) Membrane currents in taste cells of the rat fungiform papillae: evidence for two types of Ca currents and inhibition of K currents by saccharin. J Gen Physiol 96:1061-1084.

Beidler LM, Smallman R (1965) Renewal of cells within taste buds. J Cell Biol 27:263-272.

Bieber SL, Smith DV (1986) Multivariate analysis of sensory data: a comparison of methods. Chem Senses 11:19-47.

Boughter Jr JD, Gilbertson TA (1999) From channels to behavior: an integrative model of $\mathrm{NaCl}$ taste. Neuron 22:213-215.

Caicedo A, Roper SD (2001) Taste receptor cells that discriminate between bitter stimuli. Science 291:1557-1560.

Chandrashekar J, Mueller KL, Hoon MA, Adler E, Feng L, Guo W, Zuker CS, Ryba JP (2000) T2Rs function as bitter taste receptors. Cell 100:703-711.

Chang F-CT, Scott TR (1984) Conditioned taste aversions modify neural responses in the rat nucleus tractus solitarius. J Neurosci 4:1850-1862.

Chen Y, Herness MS (1997) Electrophysiological actions of quinine on voltage-dependent currents in dissociated rat taste cells. Pflügers Arch 434:215-226.

Chen Y, Sun X-D, Herness MS (1996) Characteristics of action potentials and their underlying outward currents in rat taste receptor cells. J Neurophysiol 75:820-831. 
Contreras R, Frank M (1979) Sodium deprivation alters neural responses to gustatory stimuli. J Gen Physiol 73:569-594.

Cummings TA, Daniels C, Kinnamon SC (1996) Sweet taste transduction in hamster: sweeteners and cyclic nucleotides depolarize taste cells by reducing a $\mathrm{K}^{+}$current. J Neurophysiol 75:1256-1263.

Doetsch GS, Erickson RP (1970) Synaptic processing of taste-quality information in the nucleus tractus solitarius of the rat. J Neurophysiol 23:490-507.

Erickson RP (1968) Stimulus coding in topographic and nontopographic afferent modalities: on the significance of the activity of individual sensory neurons. Psychol Rev 75:447-465.

Erickson RP, Doetsch GS, Marshall DA (1965) The gustatory neural response function. J Gen Physiol 49:247-263.

Everitt B (1980) Cluster analysis. New York: Halsted.

Farbman AI (1980) Renewal of taste bud cells in rat circumvallate papillae. Cell Tissue Kinet 13:349-357.

Frank M, Pfaffmann C (1969) Taste nerve fibers: a random distribution of sensitivities to four tastes. Science 164:1183-1185.

Frank ME, Contreras RJ, Hettinger TP (1983) Nerve fiber sensitivities to ionic taste stimuli in chorda tympani of the rat. J Neurophysiol 50:941-960.

Frank ME, Bieber SL, Smith DV (1988) The organization of taste sensibilities in hamster chorda tympani nerve fibers. J Gen Physiol 91:861-896.

Furue H, Yoshii K (1997) In situ tight-seal recordings of taste substanceelicited action currents and voltage-gated Ba currents from single taste bud cells in the peeled epithelium of mouse tongue. Brain Res 776:133-139.

Furue H, Yoshii K (1998) A method for in-situ tight-seal recordings from single taste bud cells of mice. J Neurosci Methods 84:109-114.

Gilbertson TA (1995) Patch-clamping of taste cells in hamster and rat. In: Experimental cell biology of taste and olfaction: current techniques and protocols (Spielman AI, Brand JG, eds), pp 317-328. Boca Raton, FL: CRC.

Gilbertson TA, Zhang H (1998) Characterization of sodium transport in gustatory epithelia from the hamster and rat. Chem Senses 23:283-293.

Gilbertson TA, Avenet P, Kinnamon SC, Roper SD (1992) Proton currents through amiloride-sensitive $\mathrm{Na}^{+}$channels in hamster taste cells: role in acid transduction. J Gen Physiol 100:803-824.

Gilbertson TA, Roper SD, Kinnamon SC (1993) Proton currents through amiloride-sensitive $\mathrm{Na}^{+}$channels in isolated hamster taste cells: enhancement by vasopressin and cAMP. Neuron 10:931-942.

Gilbertson TA, Fontenot DT, Zhang H, Liu L, Monroe WT (1997) Fatty acid modulation of $\mathrm{K}^{+}$channels in taste receptor cells: gustatory cues for dietary fat. Am J Physiol 272:C1203-C1210.

Gilbertson TA, Zhang H, Boughter Jr JD, Smith DV (1999) Multiple sensitivity of rat fungiform taste cells: whole cell responses to apical chemical stimulation. Chem Senses 24:569.

Giza BK, Scott TR (1991) The effect of amiloride on taste-evoked activity in the nucleus tractus solitarius of the rat. Brain Res 550:247-256

Hamill OP, Marty A, Neher E, Sakmann B, Sigworth FJ (1981) Improved patch-clamp techniques for high-resolution current recording from cells and cell-free membrane patches. Pflügers Arch 391:561-577.

Harris DE, Gilbertson DM, Monroe WT, Kinnamon SC, Gilbertson TA (1994) Contribution of amiloride-sensitive pathways to acid transduction in rats. Chem Senses 19:481-482.

Herness MS, Gilbertson TA (1999) Cellular mechanisms of taste transduction. Annu Rev Physiol 61:873-900.

Herness MS, Sun X-D (1995) Voltage-dependent sodium currents recorded from dissociated rat taste cells. J Membr Biol 146:73-84.

Kimura K, Beidler LM (1961) Microelectrode study of taste receptor of rat and hamster. J Cell Comp Physiol 58:131-140.

Kinnamon S (1988) Taste transduction: a diversity of mechanisms. Trends Neurosci 11:491-496.

Kinnamon SC, Dionne VE, Beam KG (1988) Apical localization of $\mathrm{K}^{+}$ channels in taste cells provides the basis for sour transduction. Proc Natl Acad Sci USA 85:7023-7027.

Lindemann B (1996) Taste reception. Physiol Rev 76:719-766.

Mackay-Sim A, Delay RJ, Roper SD, Kinnamon SC (1996) Development of voltage-dependent currents in taste receptor cells. J Comp Neurol 365:278-288.

Miyamoto T, Fujiyama R, Okada Y, Sato T (1998) Sour transduction involves activation of NPPB-sensitive conductance in mouse taste cells. J Neurophysiol 80:1852-1859.

Monroe WT, Smith DV, Gilbertson TA (1996) The MU chamber: a new method to record electrophysiological responses of taste receptor cells to gustatory stimuli. Chem Senses 21:644-645.

Ninomiya Y, Funakoshi M (1988) Amiloride inhibition of responses of rat single chorda tympani fibers to chemical and electrical tongue stimulations. Brain Res 451:319-325.

Oakley B (1967) Altered taste responses from cross-regenerated taste nerves in the rat. In: Olfaction and taste II (Hayashi T, ed), pp 535-547. London: Pergamon.

Oakley B (1975) Receptive fields of cat taste fibers. Chem Senses Flav 1:431-442.

Ogawa H, Sato M, Yamashita S (1968) Multiple sensitivity of chorda tympani fibres of the rat and hamster to gustatory and thermal stimuli. J Physiol (Lond) 199:223-240.

Ohtubo Y, Suemitsu T, Shobara S, Matsumoto T, Kumazawa T, Yoshii K (2001) Optical recordings of taste responses from fungiform papillae of mouse in situ. J Physiol (Lond) 530:287-293.

Ozeki M, Sato M (1972) Responses of gustatory cells in the tongue of rat to stimuli representing four taste qualities. Comp Biochem Physiol [A] 41:391-407.

Pfaff DW (1975) Theoretical consideration of cross-fiber pattern coding in the neural signalling of pheromones and other chemical stimuli. Psychoneuroendocrinology 1:79-93.

Pfaffmann C (1955) Gustatory nerve impulses in rat, cat and rabbit. J Neurophysiol 18:429-440.

Pfaffmann C (1959) The afferent code for sensory quality. Am Psychol $14: 226-232$

Roper SD (1983) Regenerative impulses in taste cells. Science 220:1311-1312.

Roper SD (1993) Synaptic interactions in taste buds. In: Mechanisms of taste transduction (Simon SA, Roper SD, eds), pp 275-293. Boca Raton, FL: CRC

Roper SD, McBride Jr DW (1989) The distribution of ion channels on taste cells and its relationship to chemosensory transduction. J Membr Biol 109:29-39.

Sato T, Beidler LM (1982) The response characteristics of rat taste cells to four basic taste stimuli. Comp Biochem Physiol A 73:1-10.

Sato T, Beidler LM (1997) Broad tuning of rat taste cells to four basic taste stimuli. Chem Senses 22:287-293.

Seto E, Hayashi Y, Mori T (1999) Patch clamp recording of the responses to three bitter stimuli in mouse taste cells. Cell Mol Biol 45:317-325.

Shannon CE, Weaver W (1959) The mathematical theory of communication. Urbana: University of Illinois.

Smith DV, Frank ME (1993) Sensory coding by peripheral taste fibers. In: Mechanisms of Taste Transduction (Simon SA, Roper SD, eds), pp 295-338. Boca Raton, FL: CRC.

Smith DV, St John SJ (1999) Neural coding of gustatory information. Curr Opin Neurobiol 9:427-435.

Smith DV, Travers JB (1979) A metric for the breadth of tuning of gustatory neurons. Chem Senses Flav 4:215-229.

Smith DV, Van Buskirk RL, Travers JB, Bieber SL (1983) Coding of taste stimuli by hamster brainstem neurons. J Neurophysiol 50:541-558.

Smith DV, Som J, Boughter JD Jr, St. John SJ, Yu C, Christy RC (1999) Cellular expression of $\alpha$-gustducin and the A blood group antigen in rat fungiform taste buds cross-reinnervated by the IXth nerve. J Comp Neurol 409:118-130.

Smith DV, Zhang H, Boughter Jr JD, St. John SJ, Gilbertson TA (2000) Random distribution of gustatory sensitivities across rat taste receptor cells and brainstem neurons. Chem Senses 25:661.

Spector AC, Markison S, St. John SJ, Garcea M (1997) Sucrose vs. maltose taste discrimination by rats depends on the input of the seventh cranial nerve. Am J Physiol 272:R1210-R1218.

St. John SJ, Spector AC (1998) Behavioral discrimination between quinine and $\mathrm{KCl}$ is dependent on input from the seventh cranial nerve: implications for the functional roles of the gustatory nerves in rats. J Neurosci 18:4353-4362.

Sweazey RD, Smith DV (1987) Convergence onto hamster medullary taste neurons. Brain Res 408:173-184.

Tonosaki K, Funakoshi M (1984) Intracellular taste cell responses of mouse. Comp Biochem Physiol [A] 78:651-656.

Travers JB, Smith DV (1979) Gustatory sensitivities in neurons of the hamster nucleus tractus solitarius. Sens Processes 3:1-26.

Travers SP (1993) Orosensory processing in neural systems of the nucleus of the solitary tract. In: Mechanisms of taste transduction (Simon SA, Roper SD, eds), pp 339-394. Boca Raton, FL: CRC.

Van Buskirk RL, Smith DV (1981) Taste sensitivity of hamster parabrachial pontine neurons. J Neurophysiol 45:144-171.

Yamamoto T, Yuyama N, Kato T, Kawamura Y (1984) Gustatory responses of cortical neurons in rats. I. Response characteristics. J Neurophysiol 51:616-635.

Yan W, Rosenzweig S, Brand JG, Spielman AI (2000) Bitter taste transduction uses two second messenger systems. Chem Senses 25:687-688. 